\title{
Foraminiferal assemblages from the late Lower and Middle Cenomanian of Speeton (North Yorkshire, UK): relationships with sea-level fluctuations and watermass distribution
}

\author{
S. F. MITCHELL \\ Department of Earth Sciences, The Jane Herdman Laboratories, Liverpool University, Brownlow Street, PO Box 147, \\ Liverpool L69 3BX, UK
}

\begin{abstract}
Twenty-seven marl samples from the late Lower and Middle Cenomanian of Speeton (North Yorkshire, UK) have been studied and six benthic foraminiferal assemblages (A to $F$ ) have been recognized by cluster analysis. These assemblages can be classified according to their constituent agglutinated foraminifera. Assemblages characterized by high abundances of non-calcareous agglutinates (A and $\mathrm{E}$ ) have low numbers of planktics and are associated with cold-water pulse faunas of mid Russian affinity (belemnites, brachiopods and bivalves). These are interpreted as representing a cold North Sica watermass. Assemblages characterized by high abundances of planktics (B and C) are associated with pulse faunas that lack cold-water elements and are interpreted as representing a warm watermass. The foraminiferal assemblages are also related to sea-level fluctuations and individual asscmblages were probably depth controlled. The assemblages can, therefore. be used to construct a sea-level curve and this agrees with the placement of critical sequence stratigraphic surfaces (e.g. sequence boundaries and flooding surfaces). Journal of Micropalaeontology, 15: 37-54.
\end{abstract}

\section{INTRODUCTION}

The early Middle Cenomanian event like the CenomanianTuronian boundary event (CTBE) represented a time of major environmental change (e.g. Paul et al., 1994; Mitchell et al., in press). Both events were associated with the influx of certain faunal elements (e.g. the belemnite Actinocamax and the bivalves Oxytoma seminudum (Dames) and Lyropecten (Aequipecten) arlesiensis (Woods)), a stable carbon isotope excursion and changes in sea-level (Paul et al., 1994: Mitchell et al., 1996; Robaszynski et al., in press). Previous studies on foraminiferal changes have largely concentrated on the Cenomanian-Turonian boundary event (e.g. Jefferies, 1962; Jarvis et al., 1988). This event was characterized by extinctions of both benthic and planktic foraminifera. The mechanism usually used to explain these extinctions is the expansion of the oxygen minimum zone (Schlanger et al., 1987; Jarvis et al., 1988). Previous studies on the late Lower and early Middle Cenomanian have included those of Burnaby (1961) and Paul et al. (1994, which included a summary of the results presented here).

In this paper the foraminiferal succession from the late Lower to late Middle Cenomanian of Speeton is presented. The data obtained are analysed using various statistical techniques and the results compared with the palaeoccanographic changes that occurred during this interval.

\section{The section at Speeton}

During the late Lower and Middle Cenomanian, Speeton was situated in the Cleveland Basin on the southern margin of the Southern North Sea Basin (Fig. 1). To the south lay the East Midlands Shelf and beyond this the Anglo-Paris Basin. The section studied here is situated below Buckton Cliffs [grid ref. TA 183747] and is part of the Ferriby Chalk Formation (Wood \& Smith, 1978). Section details have previously been given by Hill (1888), Wright (1968), Jeans (1980), Paul et al. (1994) and Gale (1995).

\section{Lithostratigraphy}

The section consists of alternations of thin flaser-marls and micritic to calcarenitic, well-cemented limestones. The marls are thin, usually about $1 \mathrm{~cm}$ in thickness, but occasionally up to $10 \mathrm{~cm}$ in thickness. They have been piped down by burrows in places indicating that they are primary sedimentary phenomena and are not purely due to pressure solution. The limestones are generally coccolith-rich micrites with sparse shell fragments (predominantly inoceramid prisms and foraminifera) although two units of gritty (calcarenitic) chalk are present (the Totternhoe and Nettleton stones). Stained acetate peels indicate that the limestones have a ferroan calcite cement.

A lithostratigraphic numbering scheme for the chalk at Speeton (prefixed by SLC - Speeton Lower Chalk, above the Red Chalk - see Mitchell 1995) is shown in Fig. 2 (a key to the symbols on the graphic log is shown in Fig. 3). The succession contains a number of distinctive lithological units, these are as follows:

SLC6: six massive weathering chalk beds SLCA to F (Jeans' (1980) 6-chalk unit).

SLC8: a conspicuous massive weathering chalk bed.

SLC10A: a thin massive weathering chalk bed.

SLC11: the Totternhoe Stone (or Grey Bed of Hill, 1888), with a prominent, thick marl (SLC11A) at the base and another (SLC11C) near the top.

SLC13: prominent marl.

SLC15: prominent marl.

SLC17: the Nettleton Stone (SLC17B, a grey weathering calcarenitic chalk) overlying a prominent marl (SLC17A, the Nettleton Pycnodonte Bed of Gaunt et al., 1992).

Marl-chalk rhythms (couplets) in the Cenomanian of the Anglo-Paris Basin are currently interpreted as productivity cycles under Milankovitch climatic control (Hart, 1987; Ditchfield \& Marshall, 1989; Leary \& Ditchfield, 1989; Gale, 


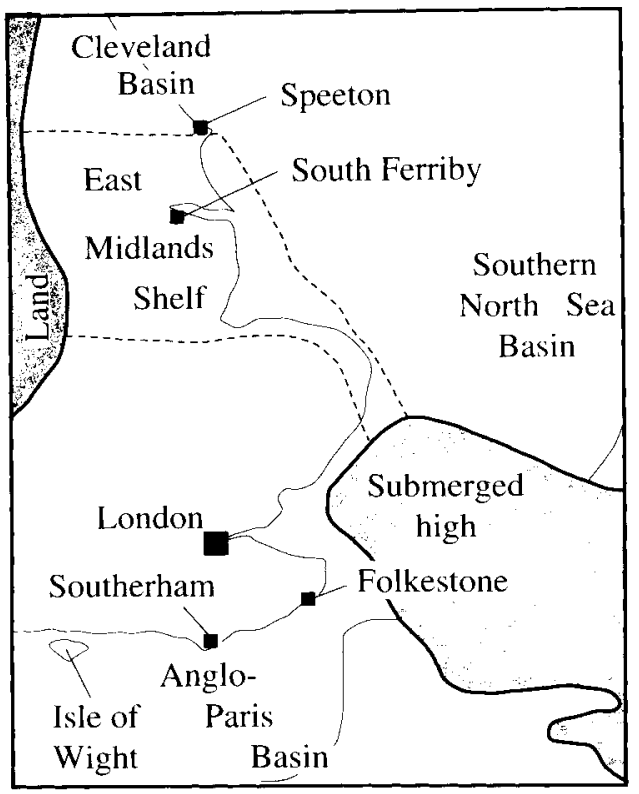

Fig. 1. Map showing locations of sections mentioned in the text.

1995). Individual, or distinctive groups of, couplets have been correlated both within the Anglo-Paris Basin (Gale, 1990) and between different basins in NW Europe (Mitchell, unpublished data; Gale, 1995) using a variety of distinctive faunal, geochemical and lithological markers. Gale (1995) demonstrated, by comparing numbers of rhythms verses radiometric dates, that these rhythms were likely to represent the Milankovitch (21 ka) precession cycle. He introduced a numbering system for these rhythms and the applicable portion of this scheme as applied to Speeton is shown in Fig. 2.

\section{Biostratigraphy}

Biozonal schemes based on ammonites, inoceramid bivalves and planktic foraminifera have been applied to the Cenomanian of NW Europe, while several other groups (belemnites, brachiopods and oysters) have been used as biostratigraphic markers. These schemes, with regard to Speeton, are discussed below.

Ammonites. Unfortunately ammonites are rare and often poorly preserved at Speeton but, where present, are invaluable. A poorly preserved example of Mantelliceras dixoni Spath was collected from bed SLC6F (Fig. 2) and this indicates the $M$. dixoni Zone of the Lower Cenomanian. Occasional, well-preserved ammonites are found in bed SLC11C; these include Acanthoceras rhotomagense (Brongniart), Turrilites costatus Lamarck and Sciponoceras baculoides (Mantell). This assemblage is characteristic of the $T$. acutus Subzone of the $A$. rhotomagense Zone. In southern England, ammonites of this subzone appear in couplet B43 (Paul et al., 1994) and the base of SLC11C (couplet C1) at Speeton can be provisionally taken as the base of the $A$. rhotomagense Zone. There is no ammonite evidence for the early Middle Cenomanian Cunningtoniceras inerme Zone at
Specton but based on couplet correlation with southern England (Mitchell, unpublished data; Paul et al., 1994) the base of this zone (and thus the base of the Middle Cenomanian) is provisionally placed in couplet B38. Diagnostic Middle Cenomanian ammonites have not been found above SLC11C and neither the Turrilites acutus Subzone or the Acanthoceras jukesbrownei Zone can be recognized at present.

Inoceramids. Inoceramid bivalves have been widely used in correlating the Cenomanian of NW Europe and this group of bivalves is common at Speeton. Zonal schemes have been developed by Keller (1982), Tröger (1989) and Wiedmann et al. (1989), while Gale (1990, 1995) has related the inoceramid succession to his couplet-based Cenomanian timescale. The distribution of inoceramids is shown in Fig. 2. Inoceramus virgatus Schluter occurs abundantly from SLC6A to SLC6F. This bioevent was recognized by Ernst et al. (1983) in NW Germany and represents Gale's (1995) B-division in the $M$. dixoni Zone (couplets B13-B18). Inoceramus schoendorfi Heinz occurs in beds SLC11A and SLC11C, the presence of this species in the former bed agrees with its placement in the $C$. inerme Ammonite Zone. Fragments of inoceramids tentatively identified as Inoceramus atlanticus (Heinz) occur in the upper part of bed SLC16 while occasional well-preserved specimens occur in the Nettleton Pycnodonte Bed (bed SLC17A). Identifiable inoceramids have not been found in the Nettleton Stone at Speeton, but the earliest examples of Inoceramus pictus Sowerby appear in the chalk bed immediately above the Nettleton Stone (Fig. 2).

Foraminifera. Planktic foraminifera, particularly the genus Rotalipora, have been used to correlate Tethyan Cenomanian successions (Robaszynski \& Caron, 1979). Unfortunately, in NW Europe many of the important planktic species are rare or absent, although a few species that occur at Speeton have proved to be useful (Paul et al., 1994). Rotalipora ex gr. reicheli Mornod has a limited distribution in Tethyan regions (Robaszynski \& Caron, 1979). At Speeton $R$. ex gr. reicheli occurs in small numbers in the marl at the base of SLC10C and relatively commonly in the prominent marl in mid bed SLC14 (Fig. 2 ). The former occurrence finds a parallel in southern England where $R$. ex gr. reicheli occurs in the marls of couplets B40 and B41 (Mitchell \& Carr, in prep.), and not with the acme occurrence in couplets B34-B36 (as implied by Paul et al., 1994, p. 726). The concentration of $R$. ex gr. reicheli in bed SLC14 is particularly significant since similar concentrations have been recognized at this level at South Ferriby (Mitchell, unpublished data) and possibly also from Bornholm, Denmark (Hart, 1979). This pulse of $R$. ex gr. reicheli in the early $T$. acutus Subzone may prove to be a valuable faunal marker in the Middle Cenomanian. The absence of Rotalipora below SLC10B means that the base of the $R$. reicheli Zone is undefined at present. Rotalipora cushmani (Morrow) appears in bed SLC13 at Speeton and marks the base of the R. cushmani Zone (Fig. 2).

Carter and Hart (1977) recognized a significant increase in 
Foraminifera from the Cenomanian of Yorkshire, UK

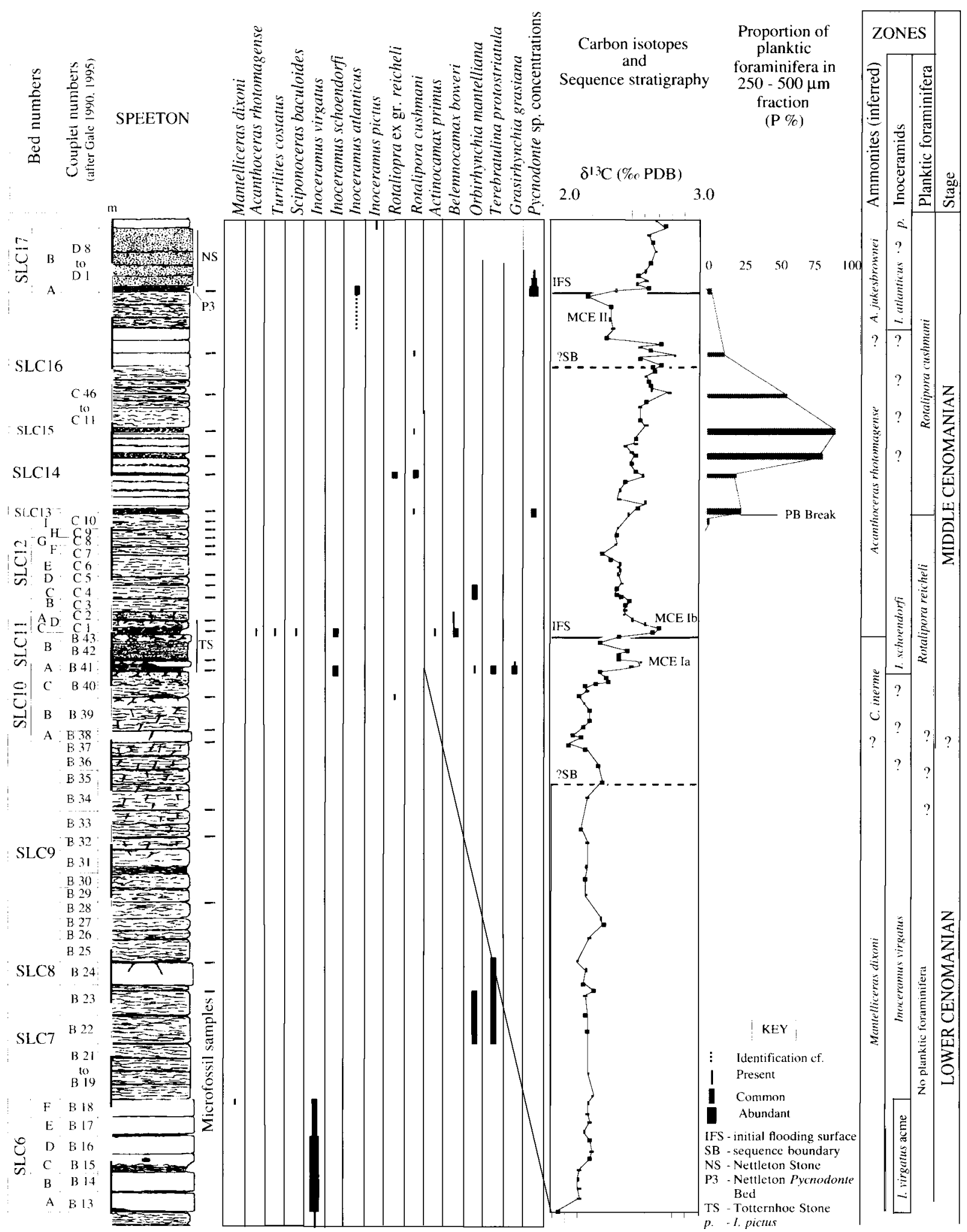

Fig. 2. Lithostratigraphy, macrofossil biostratigraphy, planktic foraminiferal biostratigraphy, sequence stratigraphy, stable isotope stratigraphy and inferred ammonite zonation of the late Lower and Middle Cenomanian at Speeton. See Fig. 3 for key to symbols on graphic log. 


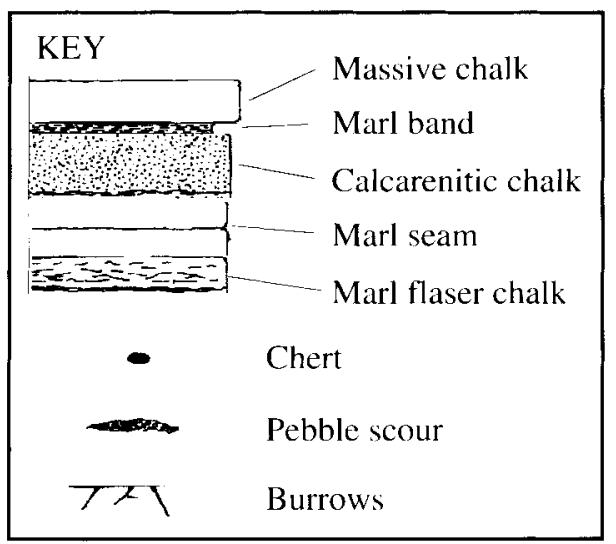

Fig. 3. Key to symbols used in the graphic logs.

the proportion of planktic foraminifera in the midCenomanian. They suggested that this represented a significant break in the succession and called it the 'mid-Cenomanian non-sequence.' This has proved to be a useful marker horizon (Carter \& Hart, 1977; Paul et al., 1994) at the base of couplet C11 (Fig. 2) for which the non-interpretative term PB break has been applied as there is no apparent break at this level (see Paul et al., 1994).

Other faunal groups. Some other fossil groups are important stratigraphically, these include belemnites, brachiopods and oysters. The belemnite Actinocamax primus Arkhangelsky is restricted to bed SLC11C (i.e. lower couplet C1) at Speeton (Fig. 2). This species occurs in lower couplet C1 throughout NW Europe (Paul et al., 1994; Gale, 1995). At Speeton this belemnite is accompanied by common examples of the small belemnite Belemnocamax boweri Crick which ranges from bed SLC11C to bed SLC12A (couplets C1-C2). This species occurs at the same level throughout NE England and in northern Gcrmany (Christensen et al., 1992).

The rhynchonellid brachiopod Orbirhynchia mantelliana (J. de C. Sowerby) occurs at three levels at Speeton (Fig. 2). The three concentrations of this species are well recorded elsewhere in NW Europe (e.g. Jeans, 1980; Gale, 1990, 1995; Paul et al. 1994) but show minor diachroneity. For instance, the lowest concentration (see Gale, 1995 for details) occurs in couplets B22-23 at Speeton, B21 at Southerham (Sussex) and B19-22 at Baddeckenstedt (Lower Saxony, Germany). These concentrations of Orbirhynchia at Speeton are also characterized by the appearance of other brachiopods that are otherwise absent: Terebratulina protostriatula Owen in the lowest pulse and $T$. protostriatula and Grasirhynchia grasiana (d'Orbigny) in the middle pulse (Fig. 2).

Concentrations of oysters have also been used as biostratigraphic markers. Small Pycnodonte sp. occur at two levels within the succession studied: beds SLC13 and SLC17A. The latter horizon (the Nettleton Pycnodonte Bed of Gaunt et al., 1992) can be traced into Germany (the Pycnodonte event of Ernst et al., 1983) and southern England (base of 'Jukes Browne's bed VII,' Jukes-Browne \& Hill, 1903: Gale, 1995).

\section{Sequence stratigraphy}

The sequence stratigraphy of the Cenomanian of the Anglo-Paris Basin has recently been documented in detail by Robaszynski et al. (in press). They recognized six horizons (onlap surfaces) which onlap the basin margins, locally onto Palaeozoic basement. Sequence boundaries preceding these onlap surfaces were placed at levels where there was a significant increase in the proportion of clay (increased acid insoluble residues).

Jeans (1980) recognized a series of fining-upwards cycles in the Cenomanian of northeast England. Each cycle commenced with a thin winnowed calcarenitic chalk, often containing glauconitized reworked pebbles, and was followed by a thicker succession of coccolith-rich chalk. It is the bases of these fining-upwards cycles that correspond with the onlap surfaces recognized by Robaszynski et al. (in press). Portions of three of these cycles are in the section considered in this paper, with the Totternhoe Stone and Nettleton Stone representing the lower portions of two of these cycles. On the East Midlands Shelf (e.g. South Ferriby, Hunstanton, etc.) the Totternhoe Stone rests on an erosion surface cut into the Lower Cenomanian and contains examples of $A$. primus (indicating lower couplet C1) and reworked chalk pebbles at its base (Jeans, 1980; Gaunt et al., 1992; Mitchell, unpublished data; Paul et al., 1994). At Speeton, however, A. primus occurs in the upper part of the Totternhoe Stone (i.e. bed SLC11C), the lower part showing a passage downwards into coccolith-rich chalks (transition in SLC10C). The base of SLC11C is interpreted as the onlap surface while the calcarenitic chalks below represent part of the lowstand deposits. In the absence of clastic (clay) input into the Cleveland Basin, sequence boundaries are difficult to recognize at Speeton and correlative horizons are suggested in Fig. 2 from the work of Robaszynski et al. (in press) in the Anglo-Paris Basin.

\section{Stable isotope geochemistry}

Stable isotopes of carbon $\left(\delta^{13} \mathrm{C}\right)$ have been used as a powerful stratigraphic tool (Scholle \& Arthur, 1980; Gale et al., 1993; Jenkyns et al., 1994; Paul et al., 1994; Mitchell et al., 1996). Within the interval considered in this paper, two short-term carbon stable isotope $\left(\delta^{13} \mathrm{C}\right)$ excursions are present, superimposed on a long-term general increase in background $\delta^{13} \mathrm{C}$ (Fig, 2). The long-term $\delta^{13} \mathrm{C}$ curve correlates with progressive sea-level rise during the Cenomanian (Hancock, 1989; Gale, 1995) and can be explained through increased storage of organic carbon in deep water masses or burial of organic carbon (Mitchell et al., 1996). The short-term excursions are associated with sequences boundaries and/or onlap surfaces (Mitchell \& Paul, 1994; Mitchell et al., 1996). The lower excursion (MCE I) is represented by two positive peaks (MCE Ia and Ib) which occur in the same couplets (peaks in B41 and C1) throughout all sections studied to date (Paul et al., 1994, Gale, 1995, Mitchell et al., 1996). The lower excursion occurs in the lowstand deposits while the upper peak occurs in the early transgressive deposits just above the onlap surface. The upper excursion (MCE II) is represented by a small negative excursion associated with lowstand deposits at Speeton. Short-term carbon excursions in the Cenomanian have been explained through changes in carbon cycling related to variations in nutrient fluxes controlled by sea-level fluctuations (Mitchell et al., 1996). 


\section{TECHNIQUES AND METHODS}

\section{Sampling and processing}

Trial attempts demonstrated that the chalks at Speeton are too strongly cemented to process for their foraminifera. In contrast, the marls are easily processed. About $200 \mathrm{~g}$ of each marl (27 samples in total) was carefully collected in the field to avoid contamination. The samples were then placed in suitable containers and processed by freeze-thawing with water until disaggregated (usually two to three freeze-thaw cycles). The residues were then sieved through standard meshes. In each case at least 300 specimens were picked from the $250-500 \mu \mathrm{m}$ size fraction. In all cases the number of specimens recovered from the $500-1000 \mu \mathrm{m}$ size fraction was significantly smaller (ty two orders of magnitude) than those present in the 250-500 um size fraction. Because of the problem of combining size fractions that are not completely picked, all statistical studies were carried out on the $250-500 \mu \mathrm{m}$ size fraction. Furthermore all species in the $500-1000 \mathrm{um}$ fraction were also present in the $250-500 \mu \mathrm{m}$ size fraction. All benthic foraminiferal data are expressed as percentages of the total benthic fauna in the $250-500 \mu \mathrm{m}$ size fraction.

Foraminiferal taxonomy follows Loeblich \& Tappan (1987) with additional data from Carter \& Hart (1977), Barnard \& Banner (1980), Hart et al. (1989) and Meyn \& Vespermann (1994), amongst others. Representative taxa are illustrated on Plate 1 and Fig. 5.

\section{Statistical techniques and indices}

While living foraminiferal assemblages provide information on biomass (i.e. species living together), fossil assemblages provide information only on species that are preserved together and are therefore dependent on changes in production rate, transport and non-preservation/dissolution. A number of statistical techniques and indices have been used in this study; these are outlined below.

$P$ (planktonic) \% and NCA (Non-Calcareous Agglutinate) \%. $\mathrm{P} \%$ is often incorrectly called the PB ratio but is actually expressed as a percentage. In modern oceans $\mathrm{P} \%$ is generally very low on shelves and high in basins, the main rise occuring either in the outer shelf or at the shelf margin (Stehli \& Creath, 1964; Kafescioglu, 1971: Gibson, 1989 and Murray, 1991). Using this as a basis, P \% has heen used to infer palaeobathymetry in the Cenomanian (Hart \& Carter, 1975; Carter \& Hart, 1977 and Hart, 1980). In this paper $\mathrm{P} \%$ is used for the proportion of planktic foraminifera in the $250-500 \mu \mathrm{m}$ size fraction expressed as a percentage of the total foraminifera.

The use of the proportion of NCA foraminifera as an index was introduced by King et al. (1989) and King (1989). NCA-dominated assemblages occur in deep water and Flysh type assemblages with low nutrient supplies (Moullade et al., 1988, Kuhnt \& Moullade, 1991 and Kuhnt et al., 1989, 1992). NCA \%, as used in this paper, is the proportion of non-calcareous agglutinated foraminifera in the $250-500 \mu \mathrm{m}$ size fraction expressed as a percentage of the total benthic foraminifera.
Diversity. The characterization of diversity is difficult because the number of taxa in a sample is dependent on the number of specimens picked. Furthermore, simply expressing the number of species present gives no information on the population structure (i.e. relative abundance of different species). In this paper three methods are used to investigate diversity. Graphical methods are frequently advocated since these provide all the information contained in the population (see Magurran, 1988 for details). In particular, rank/abundance (cumulative percentage using a complimentary logarithmic scale vs. species rank) plots can be used to differentiate communities.

The logarithmic series model was introduced by Fisher $e t$ al. (1943). This model has been widely applied to foraminiferal assemblages (see Murray, 1973,1991) and the $\alpha$-diversity index is applicable as a measure of species richness where the model holds. Values can be read from plots on previously prepared graphs (see Murray, 1991 for details). Values typically range from 5 to 20 on recent normal marine shelves and 5 to 25 in slope or bathyal environments (Murray, 1991, p. 291).

The Shannon index $\left(\mathrm{H}^{\prime}\right)$, based on information theory, is also relatively popular (Peet, 1974; Magurran, 1988). This is sensitive to both species richness and the underlying species abundance distribution. Values typically fall within the range 1-3.5 (May, 1975) with higher values representing both greater species richness and greater evenness in the species abundance distribution. For modern assemblages, $\mathrm{H}^{\prime}$ ranges from 0.6 to 2.75 on modern shelves and, 0.75 to 4.1 on slopes (Murray, 1991, p. 289).

Triangle diagrams. Triangle diagrams represent a method of plotting three variables on the same graph (strictly the relative variation) and have been widely used in foraminiferal studies. Three triangles are used here: the suborder (test structure: agglutinated vs. calcareous hyaline vs. calcareous porcellaneous) diagram (sce Murray, 1973, 1991, for details); the feeding strategy (herbivores vs. detritivores vs. suspension feeders) diagram (see Jones \& Charnock, 1985); and a diagram showing the variation in agglutinates (introduced here). The latter diagram uses the NCA, the Marssonella/Tritaxia/Pseudotextulariella and the Plectina/Arenobulimina on the vertices (see below).

Cluster analysis. Cluster analysis is a collective term for a variety of agglomerative hierarchical methods that operate on a matrix of similarities among a set of samples (Digby \& Kempton, 1987). Different clustering criteria give rise to different cluster diagrams. Complete linkage (or furthest member) cluster analysis tends to produce a large number of very compact spherical clusters, and this method of clustering has been used here. The dataset used here is particularly suitable for cluster analysis as all but one of the species range throughout the stratigraphical interval investigated. Cluster analysis, by itself, does not justify the clusters produced, but the technique can be easily integrated with other techniques such as principal component analysis (PCP).

Principal component analysis. Principal component analysis $(\mathrm{PCP})$ is an indirect ordination method that creates a new set of orthogonal axes with axes ranked to contain the maximum amount of variance possible in the sample 
(Krzanowski, 1988). For instance, in a data set of $n$ samples containing say $N$ species (i.e. $N$ dimensions expressed as orthogonal axes, where $N \leq n)$, a PCP analysis creates a new set of orthogonal axes (the eigenvectors) such that eigenvector 1 contains the greatest variance possible within the sample by one variable, eigenvector 2 the next greatest amount of variance, etc. In this manner the variation in the sample can be approximated by a smaller number of dimensions.
RESULTS AND STATISTICAL ANALYSES

The distribution of the benthic foraminifera recovered in this study is shown in Fig. 4, a list of all the benthic taxa recorded is given in Table 1 and representative taxa are shown in Plate 1 and Fig. 5. A spindle diagram showing the variation in the relative abundance of the most important taxa is shown in Fig. 6. Up section, there is a gradual reduction in the proportion of NCA taxa (particularly Ammodiscus cretaceous and Hyperammina gaultina (samples

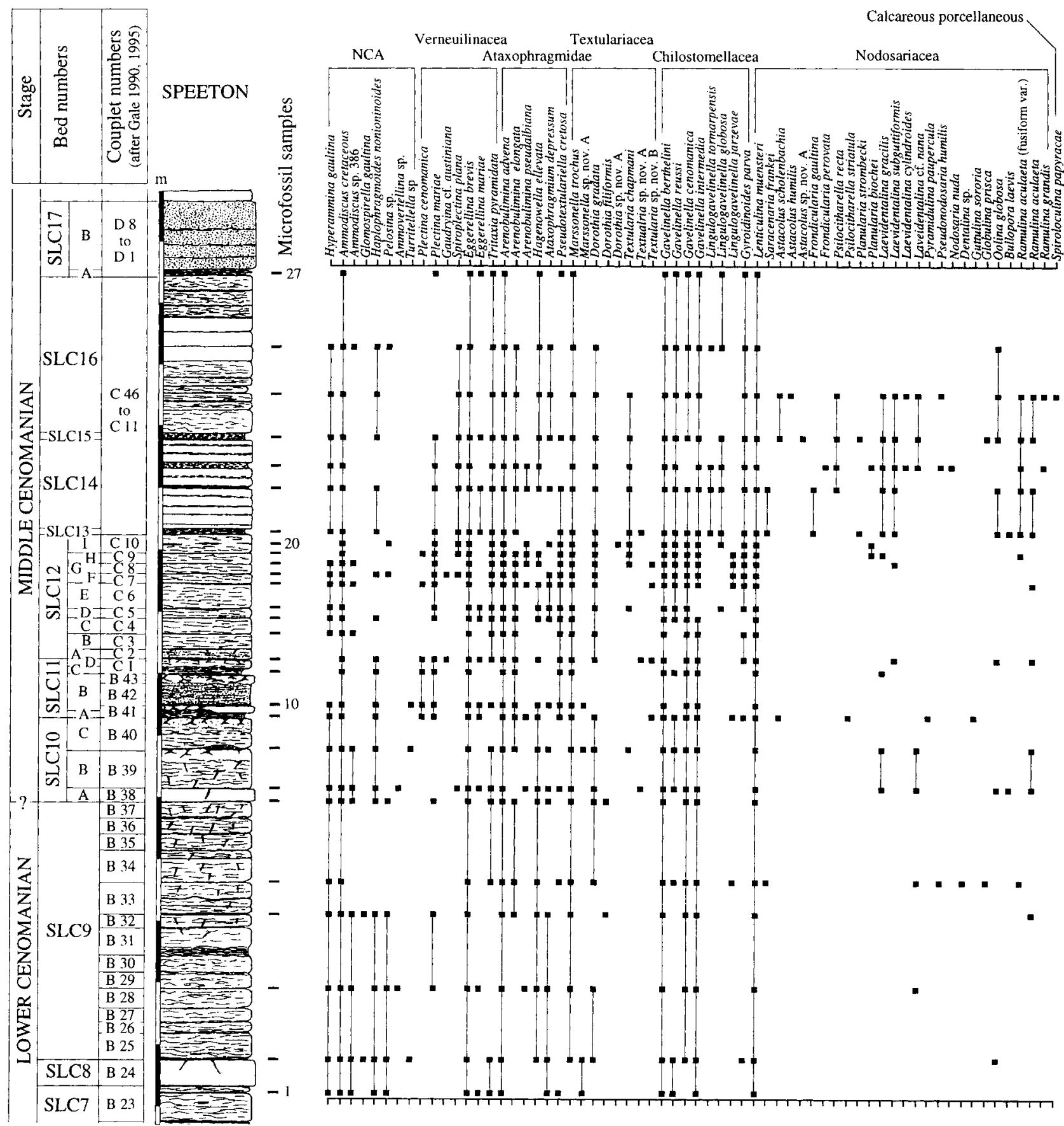

Fig. 4. Distribution of benthic foraminifera from the late Lower and Middle Cenomanian at Speeton. Successive occurrences joined. See Fig. 3 for key to symbols on graphic $\log$. 


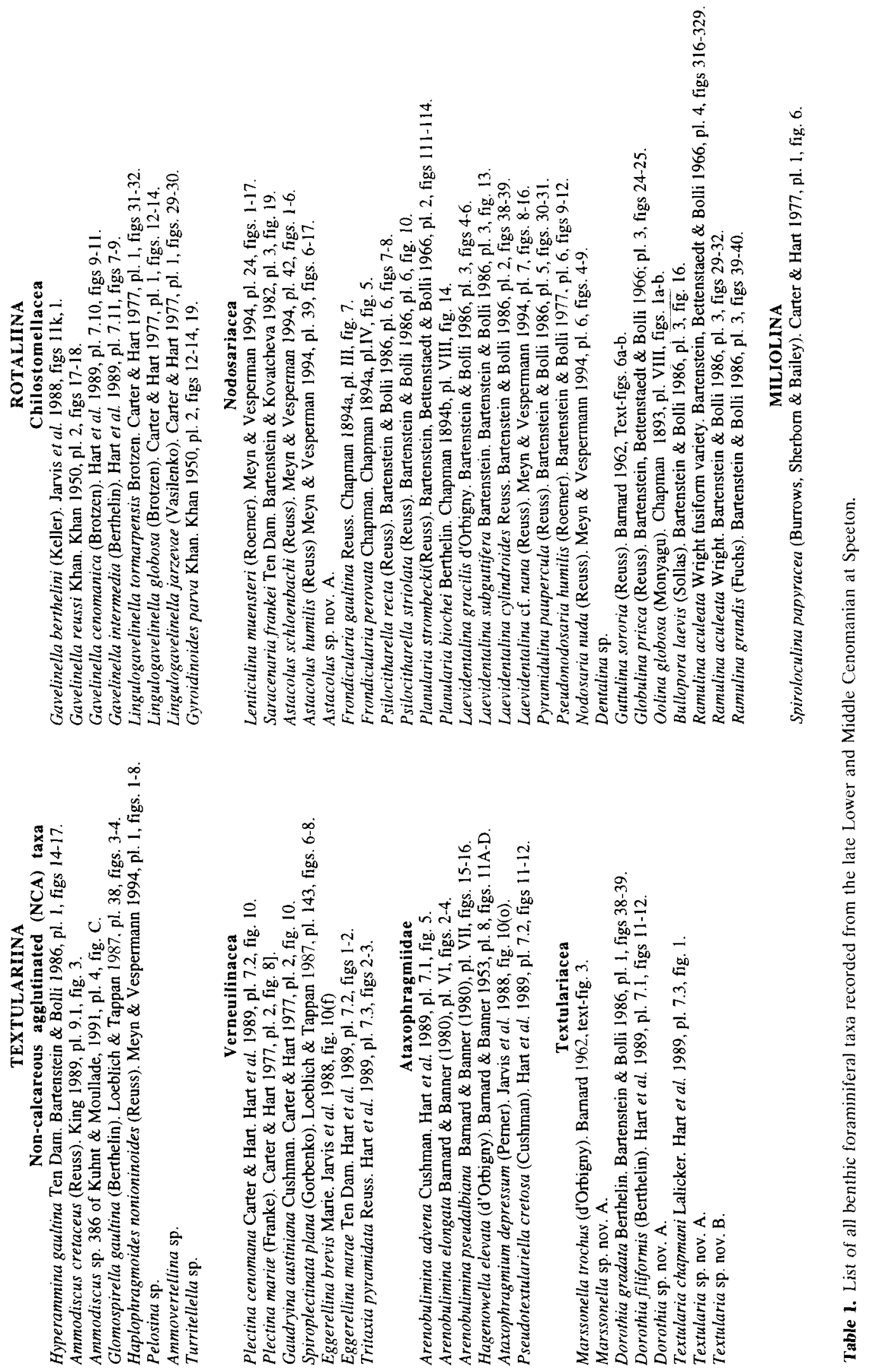



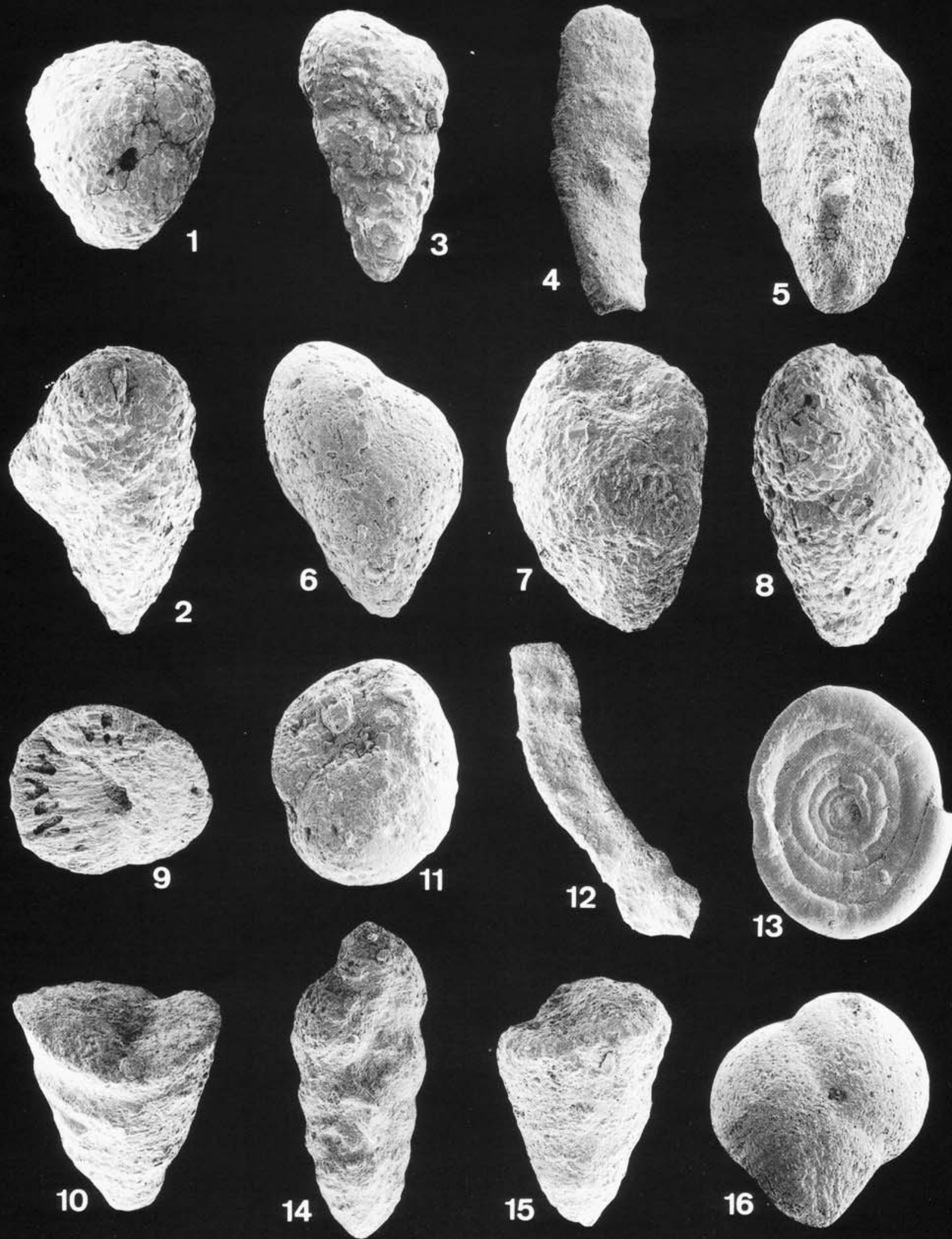
1-9), although $A$. cretaceous reappears in samples 12-18). Plectina and Arenobulimina become the most important taxa between these two pulses of NCA taxa (i.e. in samples 9-11). Above sample 15 certain calcareous agglutinated (Tritaxia pyramidata) and calcareous hyaline (Gavelinella reussi, Gyroidinoides parva and Lenticulina muensteri) taxa increase in numbers (Fig. 6).

Dissolution can be rejected as the major control on the foraminiferal assemblages for the following reasons:

(i) all the marls sampled throughout the section are visuatly very similar; (ii) calcareous taxa occur throughout;

(iii) Acid resistant taxa (Arenobulimina and NCAs) show quite different abundance patterns suggesting primary control on the assemblages;

(iv) samples with high proportions of NCA taxa contain very well preserved planktic foraminifera (e.g. sample 8).

Triangular diagrams (test structure and feeding strategy) All the samples plot within the normal marine field on the test structure diagram (Fig. 7A). On the feeding strategy

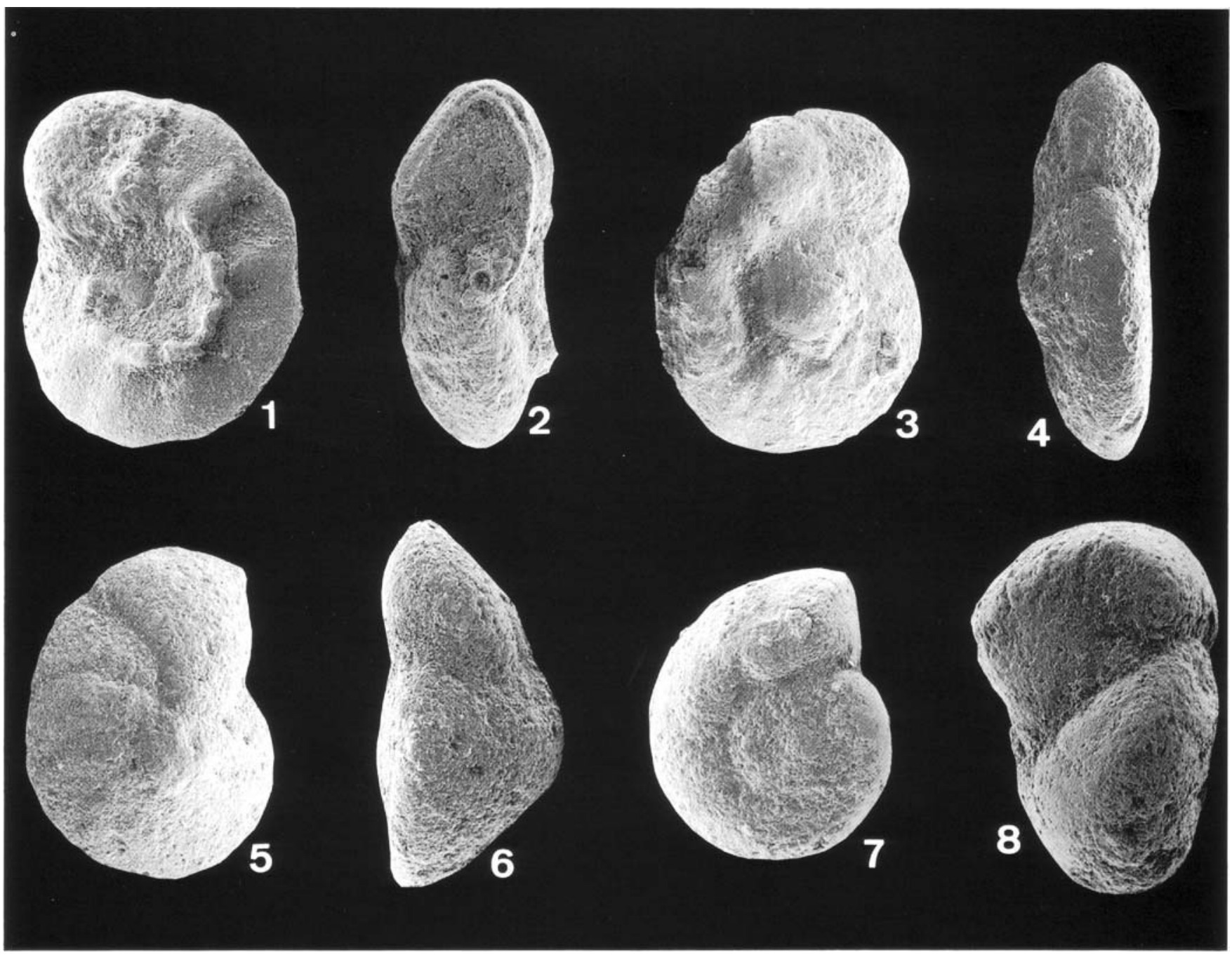

Fig. 5. Representative calcareous hyaline foraminifera from Speeton. 1-2, Gavelinella cenomanica (Brotzen), ( $\times 83) ; 3-4$, Gavelinella reussi Khan $(\times 78)$; 5-6, Gavelinella berthelini $($ Keller $)(\times 89)$ : 7-8. Gyroidinoides parva Khan $(7, \times 102 ; 8, \times 120)$. All from sample 23.

\section{Explanation of Plate 1.}

Representative agglutinated foraminifera from Speeton. Figs 1-2. Plectina cenomana Carter \& Hart, sample 11 ( $\times 58$ ): Fig. 3. Plectina mariae (Franke), sample $11(\times 58)$. Fig. 4. Spiroplectinata plana (Gorbenko), sample $23(\times 54)$. Fig. 5. Tritaxia pyramidata Reuss, sample $23(\times 69)$. Fig. 6. Arenobulimina pseudalbiana Barnard \& Banner, sample $11(\times 88)$. Figs 7-8. Arenobulimina advena Cushman. sample $11(\times 95)$. Figs $9-10$. Pseudotextuiariella cretosa (Cushman), sample 11 ( $\times 59)$. Fig. 11. Ataxophragmium depressum (Perner), sample $22(\times 68)$. Fig. 12. Hyperammina gaultina Ten Dam, sample $2(\times 47)$. Fig. 13. Ammodiscus cretaceus (Reuss), sample $2(\times 58)$. Fig. 14. Dorothia gradata Berthelin, sample 23 ( $\times 54)$. Fig. 15. Marssonella trochus (d'Orbigny), sample $23(\times 83)$. Fig. 16. Eggerellina brevis Marie, sample $23(\times 104)$ 


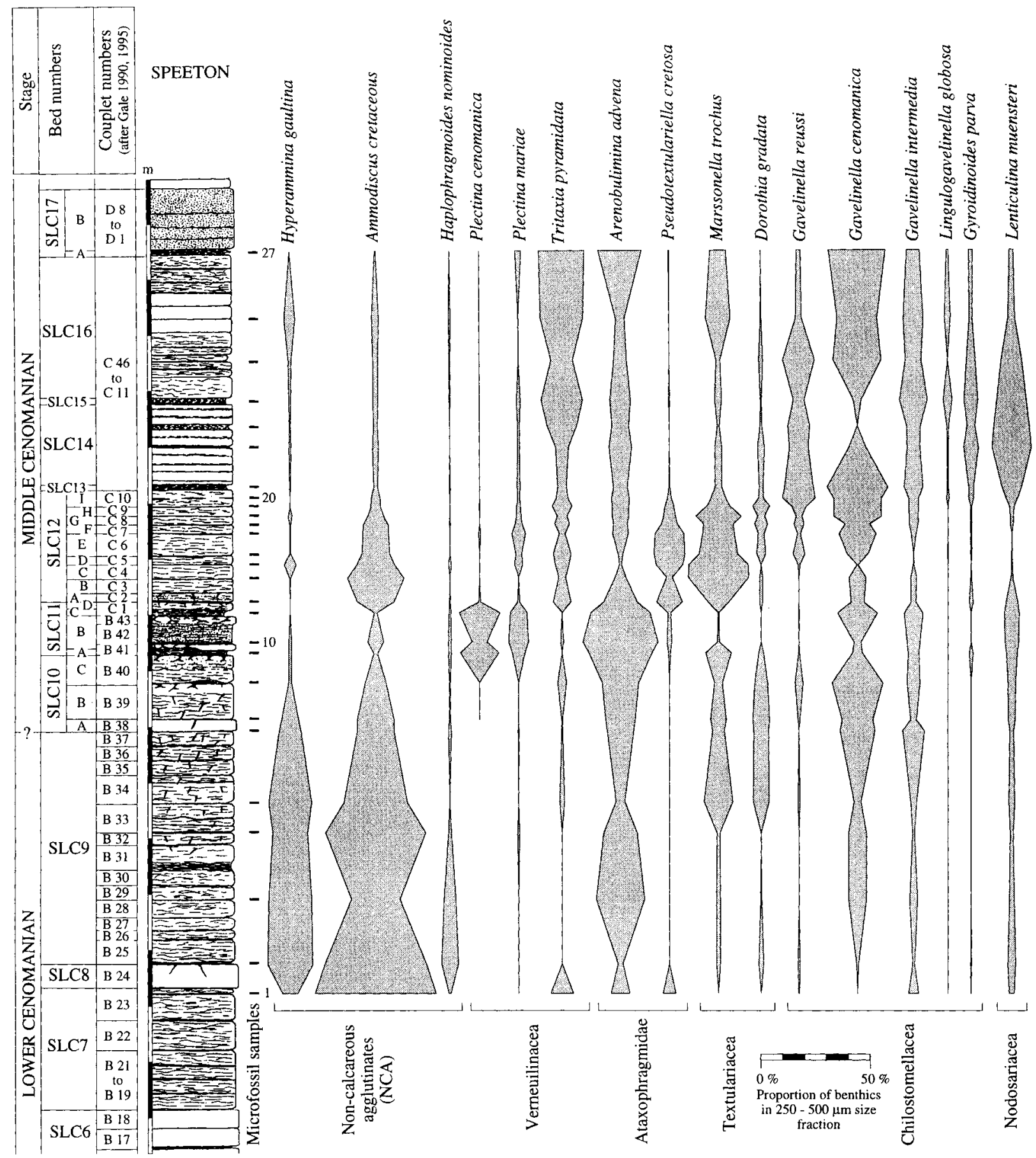

Fig. 6. Spindle diagram showing the percentage abundance of the more important benthic foraminifera from the late Lower and Middle Cenomanian at Speeton. See Fig. 3 for key to symbols on graphic log.

diagram samples $1-7$ plot in the upper bathyal field and samples 8-27 plot in the shelf field (Fig. 7B).

\section{Diversity}

Figure 8 shows a rank/abundance plot for all the samples and shows that there are significant variations in population structure. Five groups can be recognized ( 1 to 5) and these are shown in Fig. 9. All curves approximate to the log series model and this justifies the use of Fisher's $\alpha$-diversity index. The graph illustrating Fisher's $\alpha$-diversity index shows two peaks (Fig. 9): a minor one in samples 7-10 and a more significant one in samples 21-25. The Shannon index $\left(\mathrm{H}^{\prime}\right)$ graph shows a similar pattern (Fig. 9). Additionally sample 12 shows high values of both $\alpha$ and $\mathrm{H}^{\prime}$ (Fig. 9). 

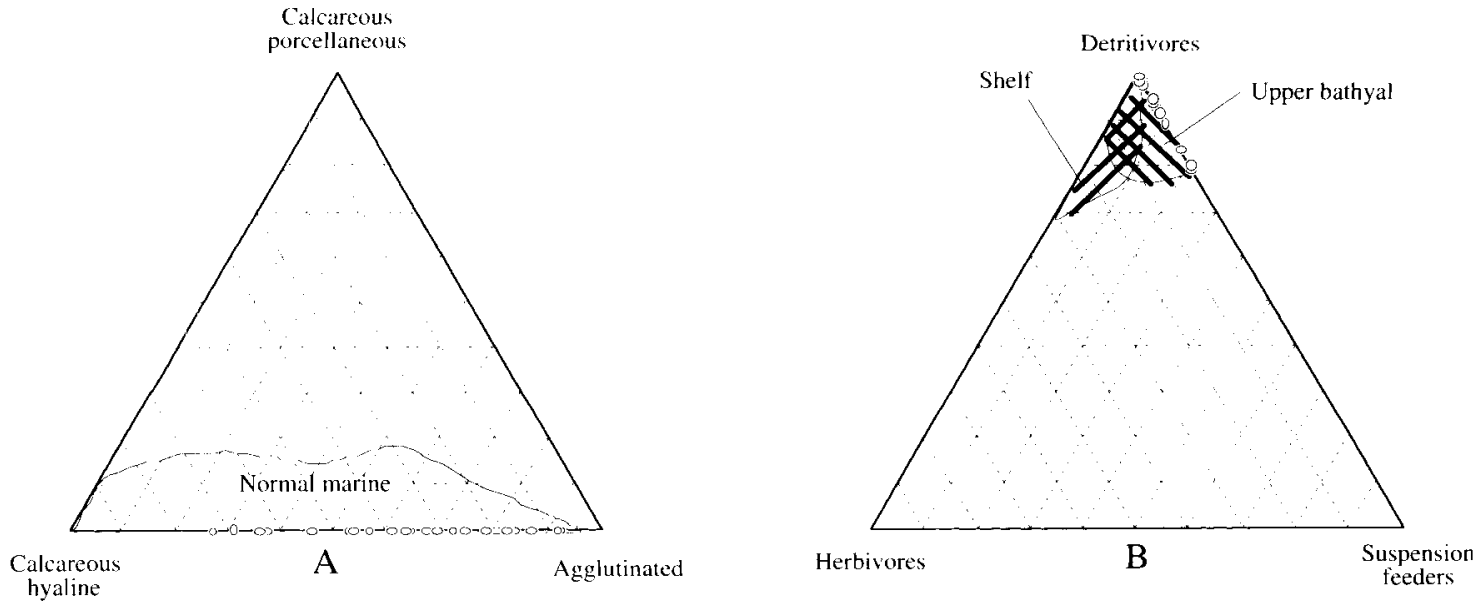

Fig. 7. Triangle diagrams. (A) test structure diagram. (B) feeding strategy diagram.

\section{Cluster analysis}

A complete linkage cluster analysis for all samples of benthic foraminifera is shown in Fig. 10. The samples cluster into six assemblages labelled $\mathrm{A}$ to $\mathrm{F}$ and the stratigraphic distribution of these is shown in Fig. 9. The relative abundance of the important benthic species (together with $\mathrm{P}$ $\%$ which was not used in the clustering) is shown in Fig. 11. Assemblages may most easily be classified by the dominant agglutinated foraminiferal species found in each assemblage.
A. Ammodiscus-Hyperammina assemblage.
B. Tritaxia assemblage.
C. Tritaxia-Marssonella assemblage.
D. Tritaxia-Marssonella-Dorothia assemblage.
E. Marssonella-Pseudotextulariella-Ammodiscus assem- blage.
F. Arenobulimina-Plectina assemblage.

It is also significant that assemblages $B$ and $C$ have significantly higher percentages of Lenticulina muensteri, Gyroidinoides parva, Gavelinella reussi, Lingulogavelinella globosa and L. tormarpensis than the other assemblages, assemblage $\mathrm{B}$ always having more than assemblage $\mathrm{C}$. This equates directly with $\mathrm{P} \%$ and suggests coeval changes in both planktic and benthic foraminiferal communities.

\section{Principal Component Analysis (PCP)}

The results of a PCP on the benthic foraminifera from Speeton is shown in Table 2. The PCP shows that $75 \%$ of the variance is represented by the first three eigenvectors. The first eigenvector accounts for $44.7 \%$ of the variance and shows a strong positive correlation with Hyperammina gaultina and Ammodiscus cretaceous and moderate negative correlations with Tritaxia pyramidata, Lenticulina muensteri and many of the Gavelinella species. The second eigenvector accounts for $19.1 \%$ of the variance and shows strong negative correlations with Arenobulimina advena and

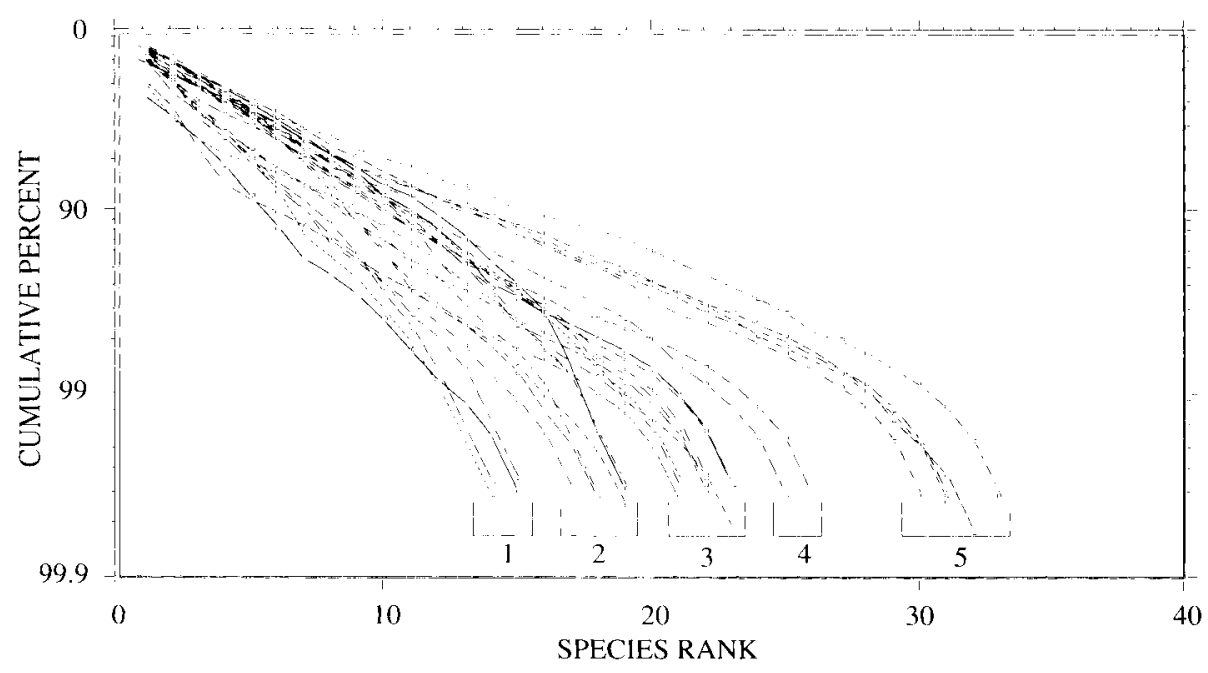

Fig. 8. Rank/abundance plot for the samples from Speeton. Note five groupings. 


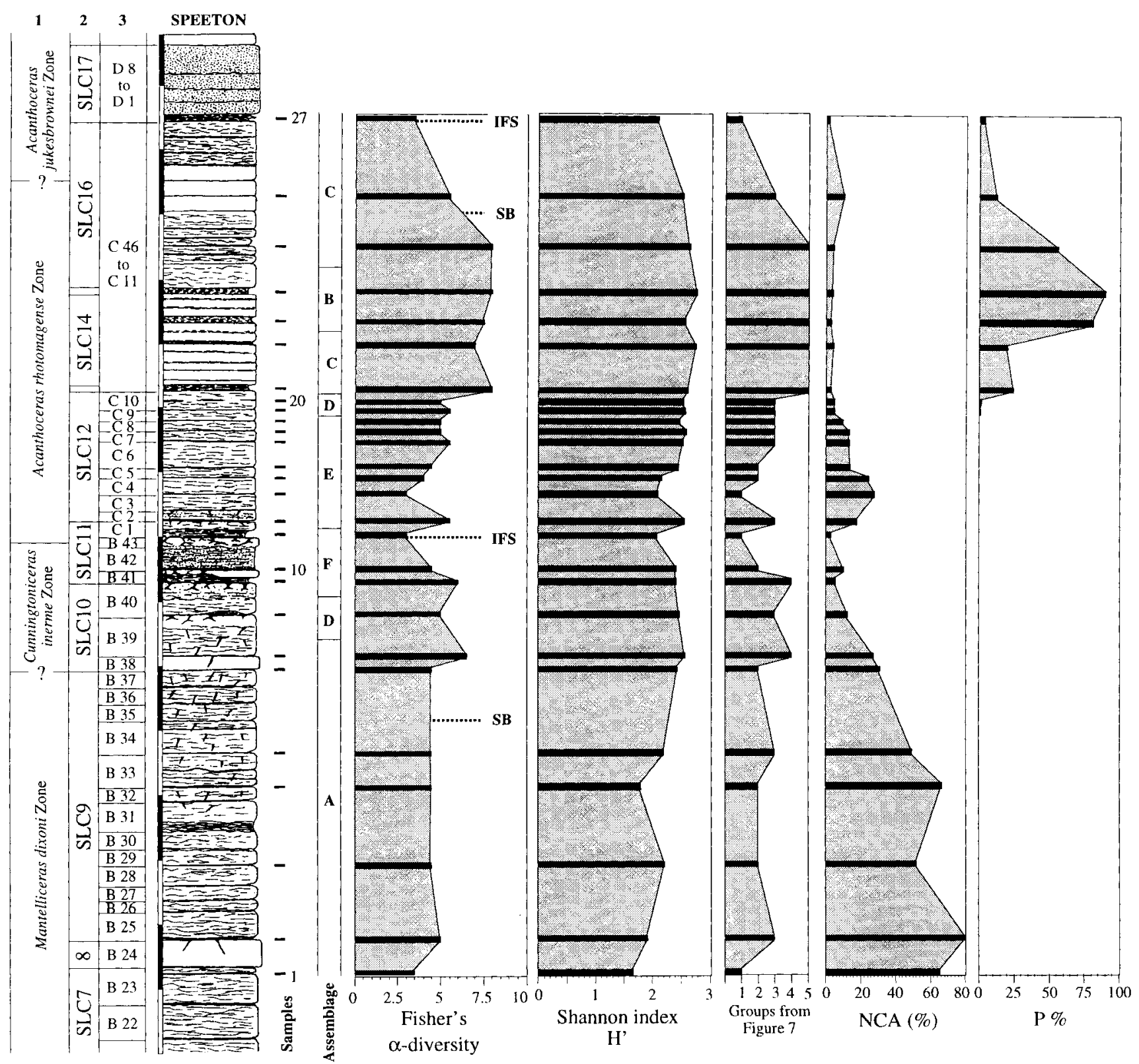

Fig. 9. Comparison between various benthic diversity indices $\left(\alpha, \mathrm{H}^{\prime}\right.$ and five groupings from Fig. 8 ) compared with $\mathrm{NCA} \%, \mathrm{P} \%$ and cluster analysis assemblages $(\mathrm{A}-\mathrm{F})$.

Plectina cenomana and moderate positive correlations with Tritaxia pyramidata, Pseudotextulariella cretosa, Marssonella trochus and Gavelinella berthelini. The third eigenvector accounts for $11.4 \%$ of the total variance and shows a positive correlation with Tritaxia pyramidata, Gavelinella reussi and Lenticulina muensteri, strong negative correlations with Pseudotextulariella cretosa and Marssonella trochus and moderate negative correlations with Plectina and Arenobulimina advena. In terms of the agglutinates, the first eigenvector may be interpreted as representing the proportion of NCAs in the assemblage, the second, the ratio between the Arenobulimina-Plectina and the Tritaxia-
Pseudotextulariella-Marssonella groups and the third, the ratio between the Tritaxia and the PseudotextulariellaMarssonella groups.

Figure 12 shows the six assemblages recognized in the cluster analysis plotted on a rotated three-dimensional plot using the first three eigenvectors as axes. This clearly separates assemblages A, E and F. Figure 13 shows the variation represented by the first two eigenvectors as a triangular diagram (vertices: NCA, Arenobulimina + Plectina, Marssonella + Tritaxia + Pseudotextulariella) and separates assemblages $A$ and $F$ from all the other assemblages. Figure 14 shows the variation represented by 
A

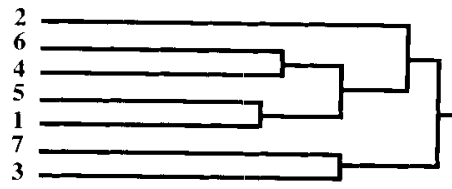

F

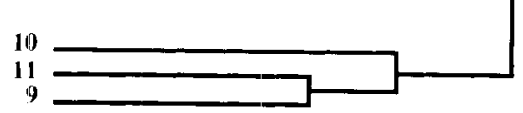

D

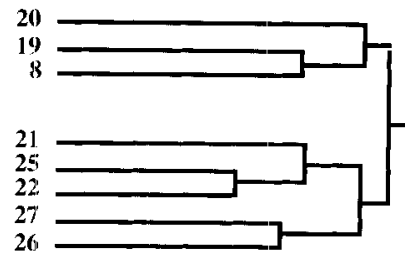

C

E

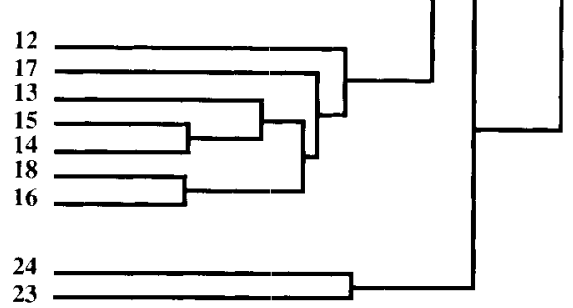

Fig. 10. Complete linkage cluster analysis of the samples of benthic foraminifera from Speeton.

the third eigenvector (proportion of Tritaxia amongst Tritaxia, Marssonella and Pseudotextulariella) plotted against NCA \% and this plot separates the remaining assemblages.

\section{INTERPRETATION}

The distribution of modern planktic foraminifera is controlled by both water depth and the distribution of different watermasses (c.g. temperature, salinity, nutrients, Murray, 1995). Previous work on the distribution of planktic foraminifera in the Cenomanian (Carter \& Hart, 1977) has largely concentrated on water depth. The PB break clearly represents a dramatic change in the mid-Cenomanian. Long-term oxygen isotope curves through the Cenomanian (Jenkyns et al., 1994) suggest a progressive warming of surface water with a reversal in this trend at the Cenomanian-Turonian boundary event. It is therefore possible that the appearance of abundant large planktic foraminifera at the PB break might be related to surface warming or the progressive northerly movement of a warm watermass.

Both long-term changes in the foraminiferal abundances and the foraminiferal assemblages (A-F) can be related to changes in sea-level. During the Cenomanian there was a progressive rise in sea level which saw the spread of chalk deposition across the whole of England (Hancock, 1989. Robaszynski et al. in press). This is reflected in the progressive increase in $\delta^{13} \mathrm{C}$ (Mitchell et al., 1996). At Speeton the foraminiferal assemblages show a change from NCA-dominated assemblages in the late Lower Cenomanian to planktic-dominated assemblages in the late Middle

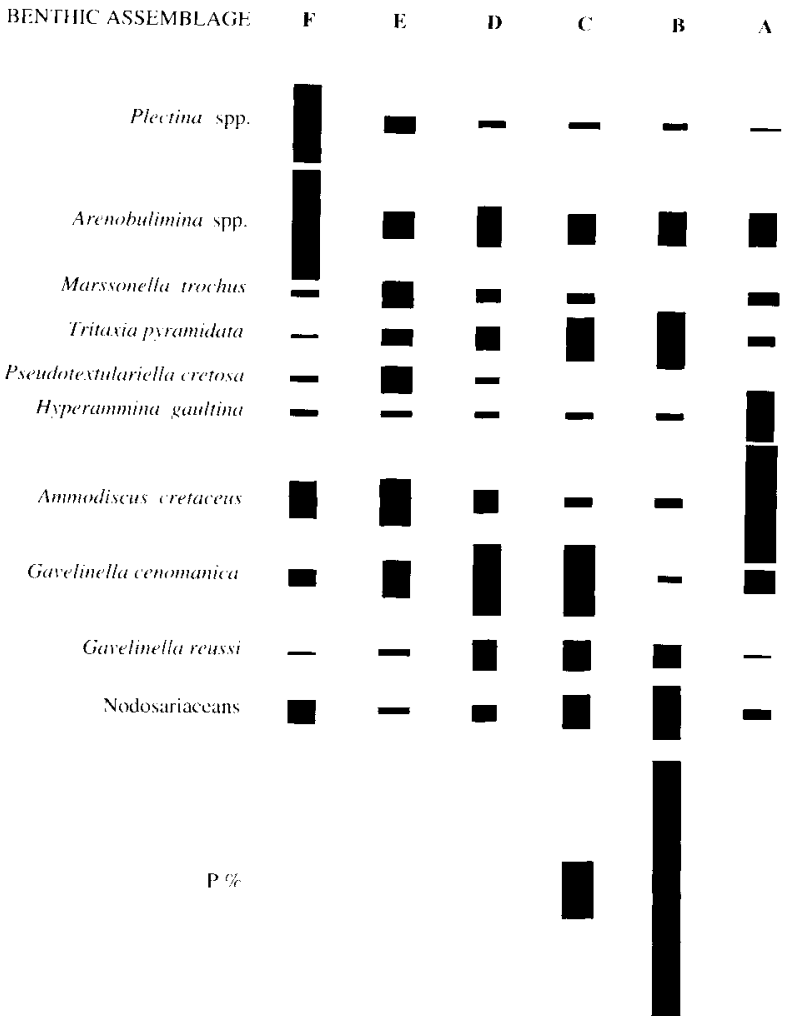

Fig. 11. Average abundance of the more important taxa in the six assemblages recognized in the cluster analysis.

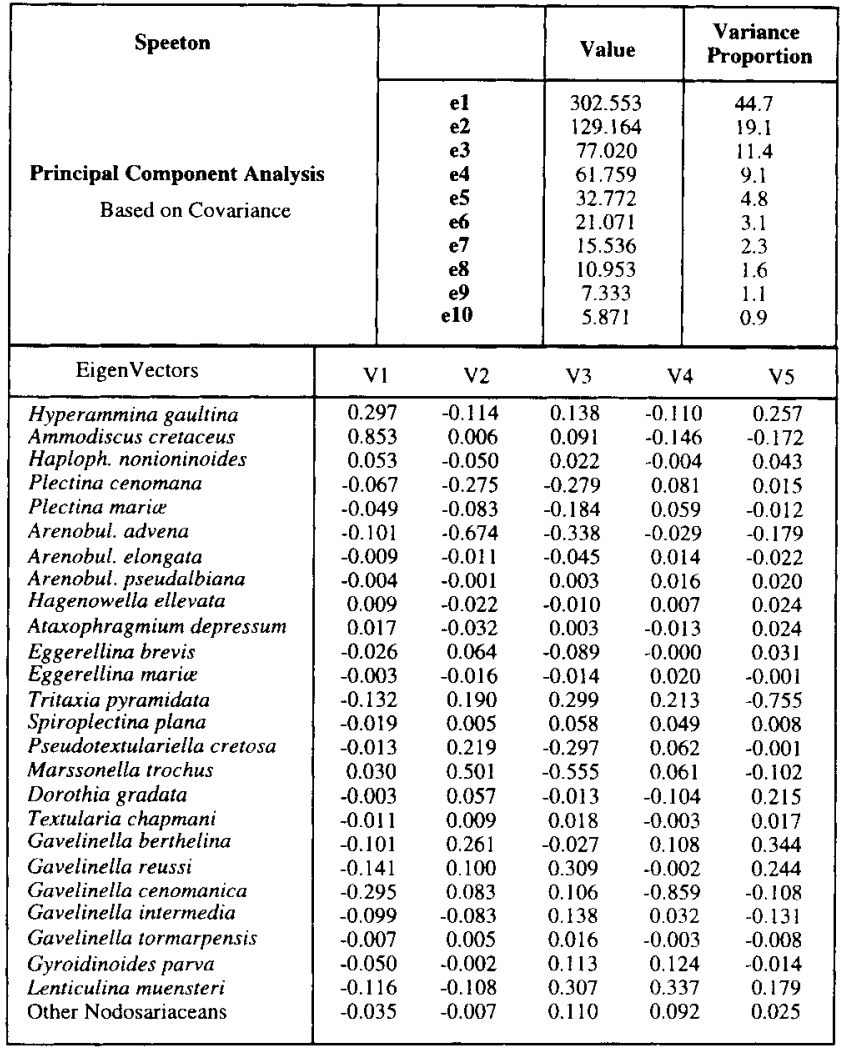

Table 2. Summary of Principal Component Analysis (PCP) of benthic foraminifera from the $250-500 \mu \mathrm{m}$ size fraction from Specton. 
S. F. Mitchell

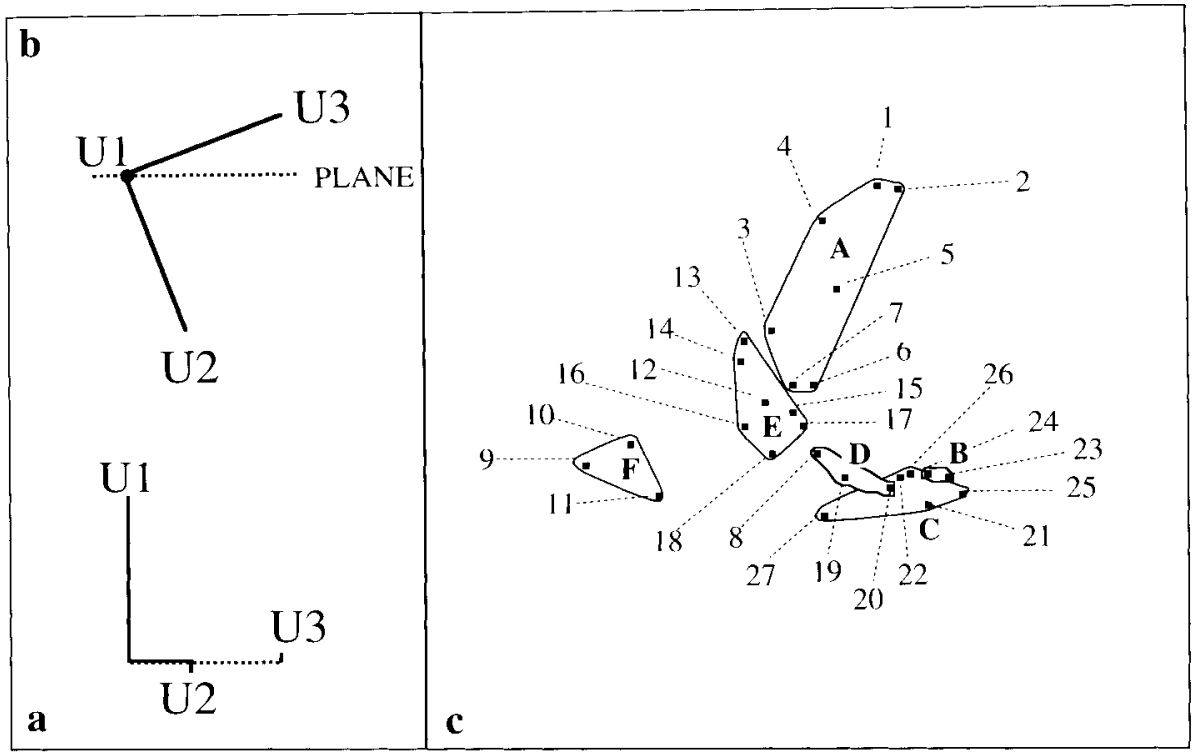

Fig. 12. Plot of six assemblages recognized in the cluster analysis on the rotated first three eigenvectors.

Cenomanian. This change in the foraminiferal assemblages can be related to more open oceanic circulation with increases in eustatic sea-level (King et al., 1989). Although the high NCA samples (1 to 7) plot in the upper bathyal field in the feeding strategy triangular plot (Fig. 7B), the low $\alpha$-diversity ( $\alpha=2.5-5.0$ ) of these samples does not suggest an upper bathyal environment (compare Murray, 1991, p. 291). These assemblages were probably controlled by nutrient supply rather than water depth (see discussion in Jones \& Charnock, 1985, p. 312-313).

At Speeton, the correlatives of the sequences recognized by Robaszynski et al. (in press) do not show alternations of NCA - and planktic-dominated assemblages that characterize long-term sea-level change. Instead, these show

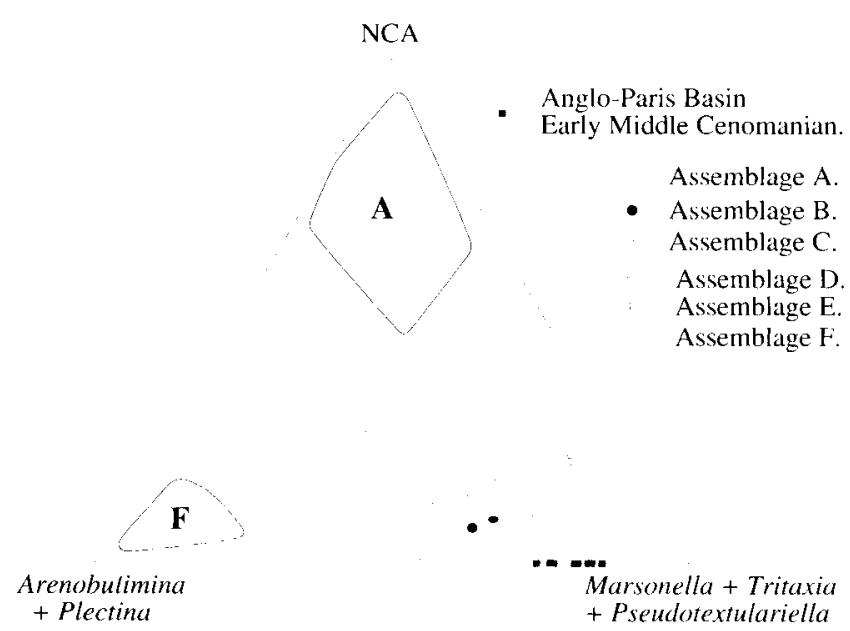

Fig. 13. Triangle diagram (based on PCP analysis). Note distinction of assemblages $\mathrm{A}$ and $\mathrm{F}$ from the cluster analysis. smaller-scale variations with the appearance of different benthic foraminiferal assemblages. The late Lower to early Middle Cenomanian sequence (Sequence 3 of Robaszynski et al. in press) is characterized by three foraminiferal assemblages (Fig. 15). The highstand deposits are characterized by assemblage A (NCA dominated) which passes to assemblages $\mathrm{D}$ and $\mathrm{F}$ in the lowstand deposits. The lowstand is also associated with an increase in diversity from $\alpha=2.5-5.0$ in the high stand deposits to $\alpha=5-7$ in the low stand deposits.

The Middle Cenomanian sequence (Sequence 4 of Robaszynski et al. in press) is characterized by a succession of foraminiferal assemblages (Fig. 15). The transgressive deposits are characterized by assemblages $E$ and $D$, the highstand deposits by assemblages $\mathrm{C}$ and $\mathrm{B}$ and the lowstand deposits by a return to assemblage $C$. Diversity is

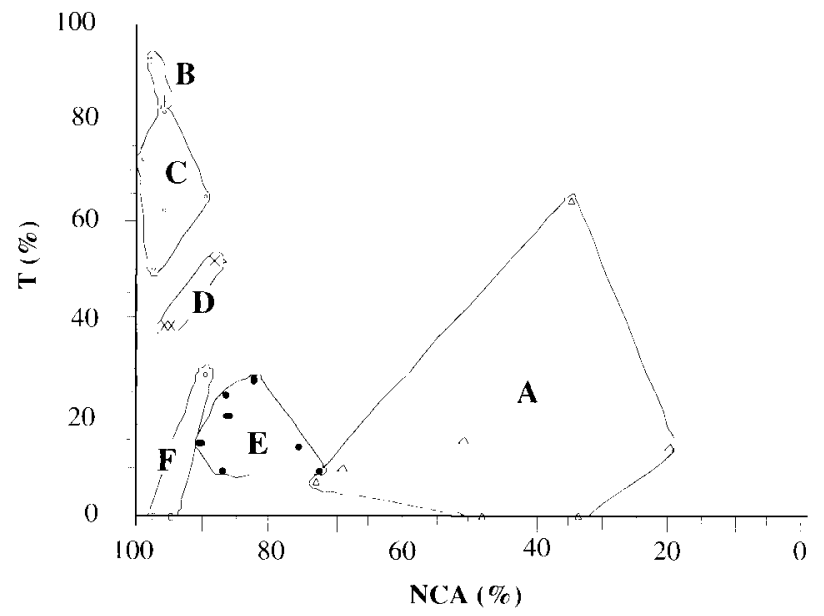

Fig. 14. Scatterplot showing $T \quad \% \quad\{$ Tritaxia/(Tritaxia + Marssonella + Pseudotextulariella) $\}$ against NCA \%, showing distinction of cluster assemblages. 


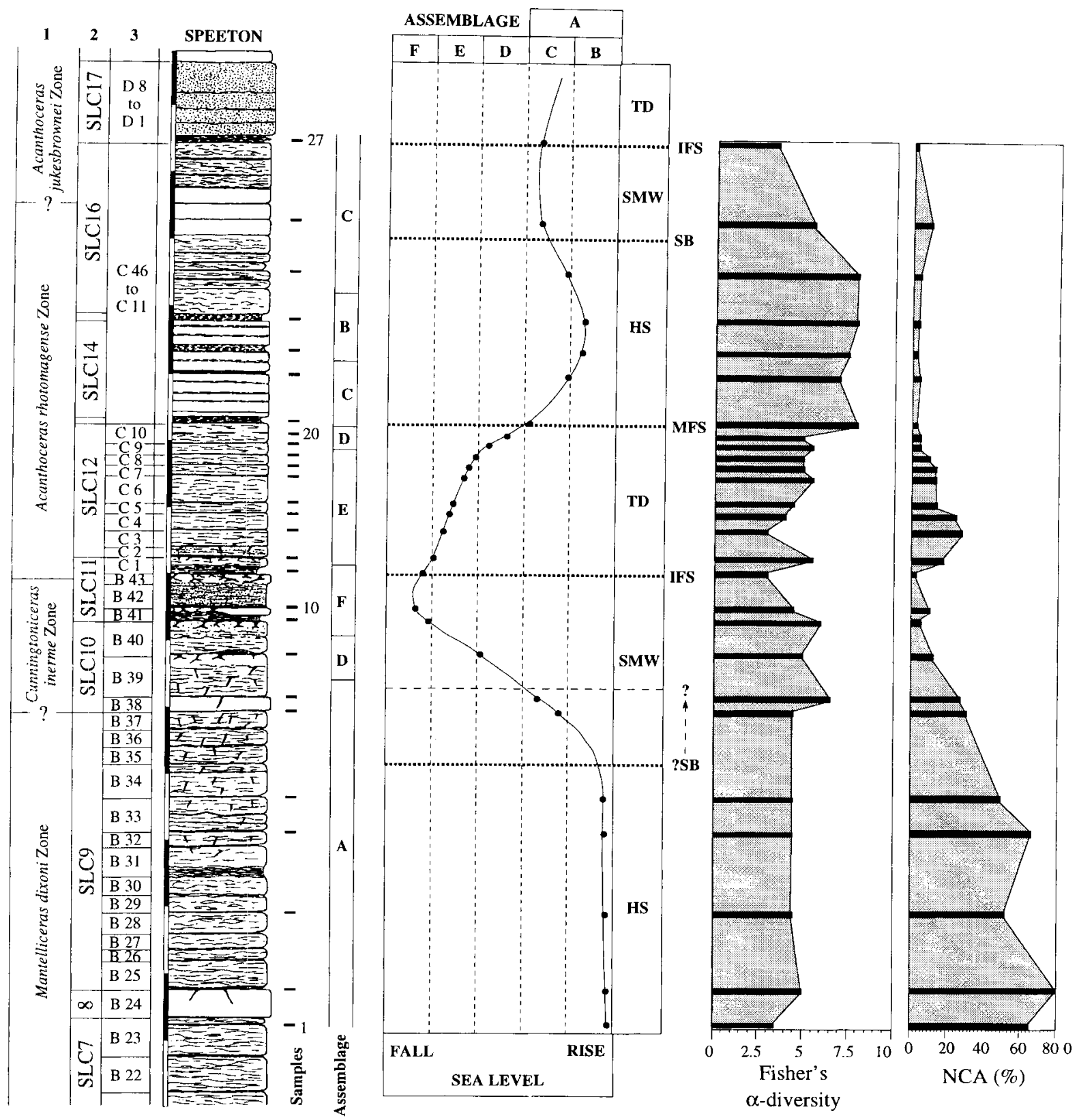

Fig. 15. Use of foraminiferal assemblages to produce sea-level curve. Note close agreement between sea-level curve and sequence stratigraphic surfaces (except lower sequence boundary which could be placed in couplet B39), and relationships with diversity and NCA \%.

low in the transgressive deposits $(\alpha=2.5-5.0)$ reaches a peak in the highstand deposits $(\alpha=7-8)$ and falls again in the lowstand deposits $(\alpha=3)$.

Burnaby (1961) discussed the depth of the benthic foraminifera from the Chalk Marl of Cambridgeshire. By comparison with living species he suggested a depth range for four taxa from the Chalk Marl. Arenobulimina spp. were interpreted as living in very shallow water, Textularia in intermediate water depths and Gyroidinoides and Tritaxia in deep water. These results are consistent with the sequence stratigraphy and foraminiferal assemblages from Speeton. In Fig. 15 a sea-level curve is constructed assuming that the foraminiferal assemblages $(\mathrm{A}-\mathrm{F})$ were depth related. This model agrees with the independently derived sequence stratigraphic surfaces (sequence boundaries and flooding surfaces), although the sequence boundary in sequence 3 (of Robaszynski et al. in press) would be better placed a little higher in couplet B39. It is perhaps significant that the highest diversities are found in the lowstand deposits in sequence 3 and the highstand deposits in sequence 4 and not in the transgressive deposits.

\section{DISCUSSION}

Jefferies (1962) studied the faunas of the plenus marls in detail and recognized the appearance of species with central Russian affinity (Actinocamax, Aequipecten (Lyropecten) 
arlesiensis, Oxytoma seminudum). He considered these to represent a cold-water migration event. In the early Middle Cenomanian a succession of similar, or the same, taxa appear in marls (the lower parts of couplets B41 and C1) characterized by a cold surface water oxygen isotope signal (see Paul et al., 1994, fig. 5). The influx of the brachiopod Orbirhynchia (together with other brachiopods of AngloParis Basin affinity in the Cleveland Basin) is also associated with these belemnite/bivalve incursions.

With progressive temperature rise during the Cenomanian (Jenkyns et al., 1994) major changes can be recognized in certain faunal groups. Cold water faunal incursions (belemnites, bivalves and brachiopods) are restricted to the interval below the PB break, where foraminiferal asscmblages are characterized by high proportions of NCAs. Above the PB break thesc cold-water faunal elements are absent and incursions are characterized only by oysters, while foraminiferal assemblages are characterized by high proportions of planktics. The PB break is interpreted as a significant level where a northern watermass with high proportions of NCAs was replaced by a southern watermass with high proportions of planktic foraminifera. A model of this general form was used by Reid (1976) to explain gross faunal changes in the whole of the Upper Cretaceous of the United Kingdom.

\section{CONCLUSIONS}

During the late Lower Cenomanian, the Cleveland and the Anglo-Paris basins had different foraminiferal assemblages and both basins lacked significant planktic taxa. The Anglo-Paris Basin was characterized by a diverse calcareous benthic assemblage including abundant Tritaxia and Gavelinella, while the Cleveland Basin contained a restricted fauna dominated by NCA foraminifera.

The sea-level fall in the early Middle Cenomanian produced a major change in the benthic fauna of the Cleveland Basin showing a transition through assemblage D (Tritaxia-Marssonella-Dorothia) to the shallow water assemblage F (Arenobulimina-Plectina) and an increase in benthic foraminiferal diversity. Associated with these foraminiferal assemblages is the appearance of a series of pulse faunas of central Russian affinity. These occur both in the Anglo-Paris Basin and in the Cleveland Basin but, in the latter, include pulse faunas of Anglo-Paris Basin affinity. It seems apparent that such incursions were times of faunal migrations due to the relatively low sea-level and the relatively southerly extension of a cool North Sea watermass.

As sea-level rose again, foraminiferal faunas underwent progressive changes in the Cleveland Basin through assemblages $E$ to $B$. Assemblage $E$ is related to the North Sea watermass and contains relatively high proportions of NCAs. Assemblage C marks the sudden appearance of vast numbers of planktic taxa characteristic of a warm water mass. The sudden influx of planktic foraminifera is synchronous across England (Paul et al., 1994) and displaces the pulse faunas of mid Russian affinity. This migration of planktic foraminifera is associated with an increase in diversity of benthic foraminifera in the Cleveland Basin. All this together suggests the rapid movement of a southerly watermass northwards displacing colder water faunas. In the Cleveland Basin planktic foraminifera increase in numbers up to assemblage B and thenceforth decrease in numbers towards the next sea-level fall in the late Middle Cenomanian. This sea-level fall is not associated with the entry of pulse faunas of cold water type but only with oyster events since both the Anglo-Paris and the Cleveland basins were under the influence of the warm water mass.

\section{ACKNOWLEDGEMENTS}

I would like to thank the following people for help at some stage with this project: Iain Carr, Dan Ellis, Ed Jones, Paul Leary, Dave Owen and Chris Paul. I am grateful to lain Carr, Marc Evans, Debbie Langner, Hazel McGoff, Chris Paul and Richard Watkins for making valuable comments on the manuscript. The isotope data used here were run at the Liverpool University Stable Isotope Laboratory funded by grants to Jim Marshall from NERC and the University. Thanks to Mr. K. J. Veltkamp for the SEM photomicrographs in Plate 1. An NERC studentship at Liverpool University is gratefully acknowledged.

\section{Manuscript received August 1992 Manuscript accepted 1995}

\section{REFERENCES}

Barnard, T. 1962. Polymorphinidae from the Upper Cretaceous of England. Palaeontology, 5: 712-726.

Barnard, T. \& Banner, F. T. 1953. Arenacaceous foraminifera from the Upper Cretaceous of England. Quarterly Journal of the Geological Society London, 109: 173-216.

Barnard, T. \& Banner, F. T. 1980. The Ataxophragmiidae of England: Par1 1, Albian-Cenomanian Arenobulimina and Crenaverneuilina. Revista Española de Micropaleontologia, 12: $383-430$

Bartenstein, H., Bettenstaedt, F. \& Bolli, H. M. 1966. Die Foraminiferen der Unterkreide von Trinidad, W.I. Zweiter Teil: Maridale-Formation (Typlokalităt). Eclogae Geologicae Helvetiae, 59: 129-177.

Bartenstein, H. \& Bolli, H. M. 1986. The foraminifera in the Lower Cretaceous of Trinidad, W.I. Part 5: Maridale Formation, upper part: Praeglobotruncana rohri Zone. Eclogae Geologicae Helvetiae, 78: 945-999.

Bartenstein, H. \& Kovatcheva, T. 1982. A comparison of Aptian foraminifera in Bulgaria and NW Germany. Eclogae Geologicae Helvetiae, 75: 621-667.

Burnaby, T. P. 1961. The palaeoecology of the foraminifera of the Chalk Marl. Palaeontology, 4: 599-608.

Carter, D. J. \& Hart, M. B. 1977. Aspects of mid-Cretaceous stratigraphical micropalaeontology. Bulletin of the British Museum of Natural History (Geology), 29: 1-135.

Chapman, F. 1893. The foraminifera of the Gault of Folkestone. Journal of the Royal Microscopical Society: Part IV, volume for $1893,579-595$.

Chapman, F. 1894a. The foraminifera of the Gault of Folkestone. Journal of the Royal Microscopical Society, Part VI (volume for 1894): $421-427$.

Chapman, F. 1894b. The foraminifera of the Gault of Folkestone. Journal of the Royal Microscopical Society, Part VII (volume for 1894): $645-654$ 
Christensen. W. K., Diedrich, C. \& Kaplan, U. 1992. Cenomanian belemnites from the Teutoburger Wald, NW Germany. Paläontologische Zeitschrift, 66: 265-275.

Digby, P. G. N. \& Kempton, R. A. 1987. Multivariate analysis of ecological communities. Population and community biology series. Chapman \& Hall, London.

Ditchfield, P. \& Marshall, J. D. 1989. Isotopic variation in rhythmically bedded chalks: paleotemperature variation in the Upper Cretaceous. Geology 17: 842-845.

Enst, G., Schmid, F. \& Seibertz. E. 1983. Event-Stratigraphic im Cenoman und Turon von NW-Deutschland. Zitteliana, 10: $531-554$.

Fisher, R. A., Corbet. A. S. \& Williams, C. B. 1943. The relation between the number of species and the number of individuals in a random sample of an animal population. Journal of Animal Ecology, 12: 42-58.

Galc, A. S. 1990. A Milankovitch scale for Cenomanian time. Terra Nova, 1: 420-425.

Gale. A. S. 1995. Cyclostratigraphy and correlation of the Cenomanian Stage in Western Europe. In House, M. R. \& Gale, A. S. (Eds) Orbital Forcing Timescales and Cyclostratigraphy. Geological Society, London, Special Publication, 85: 177-197.

Gale, A. S , Jenkyns, H. C., Kennedy, W. J. \& Corfield, R. M. 1993. Chemostratigraphy verses biostratigraphy: data from around the Cenomanian-Turonian boundary. Journal of the Geological Society, London, 150: 29-32.

Gaunt, G. D., Fletcher, T. P. \& Wood, C. J. 1992. Geology of the country around Kingston upon Hull and Brigg. British Geological Survey Sheet Memoirs, 1-172.

Gibson. T, G. 1989. Planktonic benthonic foraminiferal ratios: modern patterns and Tertiary applicability. Marine Micropalaeontology, 15: 29-52.

Hancock. J. M. 1989. Sea-level changes in the British region during the late Cretaceous. Proceedings of the Geologists' Association 100: $565-594$.

Hart. M. B. 1979. Biostratigraphy and palacozoogcography of planktonic foraminifera from the Cenomanian of Bornholm. Denmark. Newsletters on Stratigraphy, 8: 83-96.

Hart. M. 13. 1980. The recognition of mid-Cretaceous sea-leve] changes by means of foraminifera. Cretaceous Research, 1: 289-297.

Hart, M. B. 1987. Orbitally induced cycles in the Chalk facies of the United Kingdon. Cretaceous Research, 8: 335-348.

Hart, M. B., Bailey, H. W. Crittenden, S., Fletcher, B. N., Price, R. \& Swiccicki, A. 1989. Cretaceous. In Jenkins, D. G. \& Murray. J. W. (Eds) Stratigraphical Atlas of Fossil Foraminifera (second edition). British Micropalacontological Society Series, 273-371

Hart. M. B. \& Carter, D. J. 1975. Some observations on the Cretaceous foraminiferida of southeast England. Journal of Foraminiteral Research 5: 114-126.

Hill, W. 1888 . On the lower beds of the Upper Cretaceous Scries in Lincolnshire and Yorkshire. Quarterly Journal of the Geological Society, London, 44: 320-367.

Jarvis, I., Carson. G. A., Cooper, M. K. E., Hart, M. B., Leary, P., Tocher, B. A., Horne, D. \& Rosenfield, A. 1988. Microfossil assemblages and the Cenomanian-Turonian (late Cretaceous) oceanic anoxic event. Cretaceous Research, 9: 3-104

Jeans. C. V. 1980). Early submarine lithification in the Red Chalk and Lower Chalk of cast England: a bacterial control model and its implications. Proceedings of the Yorkshire Geological Society 43: $81-157$

Jefferies, R. P. S. 1962. The palacoecology of the Actinocamax plemes subzone in the Anglo-Paris Basin. Palaeontology, 4: $609-647$.

Jenkyns, H. C.. Gale, A. S. \& Corfield, R. M. 1994. Carbon- and oxygen-isotope stratigraphy of the English Chalk and Italian Scaglia and its palacoclimatic significance. Geological Magazine. 131: $1-34$.

Jones, R. S. \& Charnock. M. A. 1985. 'Morphotypes' of agglutinated foraminifera. Their life positions and feeding habits and potential applicablility in (palco) ecological studies. Revue de Paléobiologie 4: 311-20.
Jukes-Browne, A. J. \& Hill, W. 1903. The Cretaceous rocks of Britain. Volume 2, The Lower and Middle Chalk. Memoir of the Geological Survey of the United Kingdom.

Kafescioglu, A. 1971. Specific diversity of planktonic foraminifera on the continental shelf as a paleobathymetric tool. Micropaleontology, 17: 455-470.

Keller, S. 1982. Dic Oberkreide der Sack-Mulde bei Alfeld (Cenoman-Unterconiac): Lithologie, Biostratigraphie und Inoceramen. Geologisches Jarbuch $(A), 64: 3-171$.

Khan, M. H. 1950. Note on the depth and temperature of the Gault sea as indicated by foraminifera. Geological Magazine, 87: $175-180$.

King, C. 1989. Cenozoic of the North Sea. In Jenkins, D. G. \& Murray, J. W. (Eds) Stratigraphical Atlas of Fossil Foraminifera (second edition). British Micropalaeontological Society Series, $418-489$.

King, C., Bailey, H. W., Burton, C. \& King, A. D. 1989. Cretaceous of the North Sea. In Jenkins, D. G. \& Murray, J. W. (Eds) Stratigraphical Atlas of Fossil Foraminifera (second edition). British Micropalaeontological Society Series. 372-417.

Krzanowski, W. J. 1988. Principles of Multivariate Analysis: a User's Perspective. Oxford statistical science series 3m, 1-563. Clarendon Press, Oxford.

Kuhnt, W., Geroch, S., Kaminski, M. A., Moullade, M. \& Neagu, T. 1992. Upper Cretaceous abyssal claystones in the North Atlantic and Western Tethys: current status of biostratigraphical correlation using agglutinated foraminifers and palaeoceanographic events. Cretaceous research 13: 467-478.

Kuhnt, W.. Kaminski, M. A. \& Moullade. M. 1989. Late Cretaceous decp-water agglutinated foraminiferal assemblages from the North Atlantic and its marginal seas. Geologische Rundschau, 78: $1121-1140$.

Kuhnt, W. \& Moullade, M. 1991. Quantitative analysis of Upper Cretaccous abyssal agglutinated foraminiferal distribution in the North Atlantic-paleoceanographic implications. Revue de Micropaléontologie, 34: 313-349.

Leary, P. N. \& Ditchfield, P. 1989. The foraminiferal assemblage against the oxygen isotope signature through three Cenomanian (Cretaceous) marl chalk-marl rhythms from S.E. England. Mesozoic Research, 2: 75-81.

Locblich, R. L. Jr. \& Tappan, H. 1987. Foraminiferal genera and their classification. Van Nostrand Reinhold, New York (2 vols).

Magurran, A. E. 1988. Ecological Diversity and its Measurement. Croom Helm, London.

May, R. M. 1975. Patterns of species abundance and diversity. In Cody, M. L. \& Diamond, J. M. (Eds) Ecology and Evolution of Communities. Harvard University Press, 81-120.

Meyn, H. \& Vespermann, J. 1994. Taxonomische Revision von Foraminiferen der Unterkreide SE-Niedersachsens nach Roemer (1839. 1841, 1842), Koch (1851) und Reuss (1863). Senckenbergiana Lethaea, 74: 49-272.

Mitchell, S. F. 1995. The Hunstanton Red Chalk Formation (Albian-Cenomanian, Cretaceous) at Speeton, Yorkshire. Proceedings of the Yorkshire Geological Society, 50: 285-303.

Mitchell, S. F. \& Paul, C. R. C. 1994. Carbon isotopes and sequence stratigraphy. In Johnson, S. D. (Ed.) High Resolution Sequence Stratigraphy: Innovations and Applications. 28th-30th March 1994. Abstracts volume, 20-23 (1 Fig.). University of Liverpool.

Mitchell, S. F.. Paul, C. R. C. \& Gale. A. S. 1996. Carbon isotopes and sequence stratigraphy. In Howell, J. A. \& Aitken. J. F. (Eds) Sequence Stratigraphy: Innovations and Applications. Gcological Socicty, London, Special Publication, 104: 11-24.

Moullade, M., Kuhnt, W. \& Thurow, J. 1988. Agglutinated benthic foraminifers from Upper Cretaceous variegated clays of the North Atlantic Ocean (DSDP Leg 93 and ODP Leg 103). In Boillot,G.. Winterer, E. L. et al. Proceedings of the Ocean Drilling Program, Scientific Results 103: 349-377.

Murray, J. W. 1973. Distribution and ecology of living benthic Foraminiferids. Hcinemann, London.

Murray, J. W. 1991. Ecology and Palaeoecology of Benthic Foraminifera. Longman Scientific and Technical, Harlow. 
Murray, J. W. 1995. Microfossil indicators of ocean water masses. circulation and climate. In Bosence, W. J. \& Allison, P. A. (Eds) Marine Palaeoenvironmental Analysis from Fossils. Geological Society, London, Special Publication, 83: 245-264.

Paul, C. R. C., Mitchell, S. F., Ditchfield, P. W.. Gale, A. S., Leary, P. N. \& Marshall, J. D. 1994. Palaeoceanographic events in the Middle Cenomanian of Northwest Europe. Cretaceous Research, 15: $707-738$.

Peet, R. K. 1974. The measurement of species diversity. Annual Review of Ecological Systematics 5: 285-307.

Reid, R. E. H. 1976. Late Cretaceous climatic trends, faunas and hydrography in Britain and Ireland. Geological Magazine 113: $115-128$.

Robaszynski, F. \& Caron, M. 1979. Atlas of mid-Cretaceous planktonic foraminifera (Boreal Sea and Tethys). Cahiers de Micropaléontologie, Part 1, 1-185; Part 2, 1-181.

Robaszynski, F., Juignet, P., Gale, A. S., Amedro, F. \& Hardenbol, J. (in press). Sequence stratigraphy in the Upper Cretaceous of the Anglo-Paris Basin: exemplified by the Cenomanian Stage. In Jaquin, T.. De Graciansky, P. \& Hardenbol, J. (Eds) Sequence Stratigraphy. Society of Economic Paleontologists and Mineralogists. Special Publication.

Schlanger, S. O., Arthur, M. A., Jenkyns, H. C. \& Scholle, P. A. 1987. The Cenomanian-Turonian oceanic anoxic event, I. Stratigraphy and distribution of organic carbon-rich beds and the marine $\delta^{1.3}$ C excursion. In Brooks, J. \& Fleet, A. J. (Eds) Marine
Petroleum Source Rocks. Geological Society, London, Special Publication, 26, 371-399.

Scholle, P. A. \& Arthur. M. A. 1980. Carbon isotope fluctuations in Cretaceous pelagic limestones: potential stratigraphic and petrolcum exploration tool. Bulletin of the American Association of Petroleum Geologists, 64, 67-87.

Stehli, F. G. \& Creath, W. B. 1964. Foraminiferal ratios and regional environments. Bulletin of the American Association of Petroleum Geologists, 48: 1810-1827.

Tröger, K.-A. 1989. Problems of Upper Cretaceous inoceramid biostratigraphy and paleobiogegraphy in Europe and Western Asia. In Wiedmann, J. (Ed.) Cretaceous of the Western Tethys. Proceedings of the 3rd International Cretaceous Symposium, Tübingen 1987, Schweizerbart'sche, Stuttgart, 911-930.

Wiedmann, J., Kaplan, U., Lehmann, J. \& Marcinowski, R. 1989 Biostratigraphy of the Cenomanian of NW Germany. In Wiedmann, j. (Ed.) Cretaceous of the Western Tethys. Procecdings of the 3rd International Cretaceous Symposium, Tübingen 1987, Schweizerbart'sche, Stuttgart, 931-948.

Wood, C. V. \& Smith, E. G. 1978. Lithostratigraphical classification of the Chalk in North Yorkshire, Humberside and Lincolnshire. Proceedings of the Yorkshire Geological Society, 42: 263-287.

Wright, C. W. 1968. Itinerary IX. Reighton Gap to Speeton Cliffs. In Hemingway, J. E., Wilson, V. \& Wright, C. W. Geologists Association Guides. 34: Geology of the Yorkshire Coast, $39-$ 44. 